infection and vice versa. There was also a tendency towards an increased proportion of ware-sized tubers in years of slow development of blight on the foliage.

\section{Flanged Steel Plug Valves for the Petroleum Industry}

British Standard 1570 (1949), which bears the title "Flanged Steel Plug Valves for the Petroleum Industry" (pp. 31 ; London : British Standards Institution, $1949 ; 7 s .6 d$. net), has recently been issued. It is based on American Petroleum Institute Standard $600 B$ dealing with the same subject and has the advantage, therefore, of ensuring interchangeability between American and British equipment. This specification covers the design and manufacture of flanged steel plug valves, materials involved, workmanship, dimensions, appropriate tests, marking, inspection, preparation and dispatch, and also form of manufacturer's guarantee. Appendixes are provided giving details of the materials to be used. Included are drawings of plug valves and end-flange facings as required by the various classes of valves dealt with.

\section{Application of Ultrasonics}

The May issue of the Proceedings of the Physical Society $(63 \mathrm{~B}, 305 ; 1950)$ contains a summary, by Dr. G. Bradfield, of the National Physical Laboratory, of the proceedings of the symposium on the applications of ultrasonics held by the Acoustics Group on February 18, 1949. Recent advances in the investigation of the fundamental structure of matter, telecommunications and allied applications, and the use of mechanical forces set up by intense waves were surveyed. The derivation of elastic constants of substances using single crystals was considered an important field of investigation. With regard to suitable sources of ultrasonic power, the importance of barium titanate as a powerful and strongly coupled piezo-electric transducer was pointed out. Calculated optimum frequencies for propagation over various distances with minimum attenuation for various gaseous and liquid media are in accord with those found experimentally in echo-sounding, earth explora. tion and in propagation in metals. The success of various applications of ultrasonics in industry and in navigation was discussed, and attention was directed to the present lack of industrial application of intense waves, though many spectacular laboratory experiments have been performed with them. It would appear that it is more profitable to use ultrasonic waves for irreversible actions such as killing bacteria, cleansing, dislodging oxide films, removing dissolved gases and the precipitation of aerosols.

\section{St. Ives Research Station of the Board of Green- keeping Research (1929-50)}

THE twenty-first anniversary of the St. Ives Research Station at Bingley, Yorkshire, of the Board of Greenkeeping Research was celebrated by a series of functions, at the Station, during September 14-16. The first two days were devoted to golf courses and sports grounds, respectively, and attendance was restricted to representatives of affiliated clubs and other organisations; Lord Brabazon of Tara, past president of the English Golf Union, opened the celebrations on Septernker 14, and Mr. A. Brook Hirst, chairman of the Football Association, those on September 15. On the third day the proceedings were open to the general public, who were afforded the opportunity of seeing at first hand the many ways in which the Station is helping to achieve the best possible playing conditions in all sports using turf (see Nature, July 1, p. 22). There was a series of exhibits illustrating the development of the Station's research and investigational work during the past twenty-one years, the growth of the advisory servife and the educational facilities made available by the Board; and short lectures and practical demonstrations were also given, together with a display of modern turf machinery and implements.

\section{Fuel Cell at the British Association Exhibition}

Is an article on "Energy in the Service of Man", describing the recent exhibition at Birmingham in connexion with the meeting of the British Association (Nature, September 2, p. 386), it is stated that the fuel cell exhibited was constructed by the British Coal Utilization Research Association; this is incorrect. The exhibit consisted of experimental hydrogen cells constructed in the Research Laboratories of the British Electricity Authority, with ancillary apparatus. The cells are of the type:

$\mathrm{H}_{2}$ (silver-active carbon) | aqueous $\mathrm{K}$ ) $\mathrm{H}$ | (nickcl-active carbon) $\mathrm{O}$, and are modified versions of that constructed in the U.S.S.R. by O. K. Davtyan ("Direct Conversion of Chemical Energy of Fuel into Electrical Energy", Moscow, 1947 : Academy of Sciences, U.S.S.R., 48 pp.). One of these cells was shown in operation, but it has not been possible in preliminary experiments to obtain outputs as high as those claimed by Davtyan. This simple type of cell serves to demonstrate the principle of fuel-cell action, but in order to obtain worthwhile current densities, more elaborate constructions would probably be required, such as the high-pressure cell developed by the Electrical Research Association. Even so, the high cost of hydrogen at present would make it uneconomic, so that future research must be directed towards the evolution of a cell operating on a cheaper fuel, such as water, gas, or better, coal itself. In this connexion, a diagram of a cell constructed in the laboratories of the British Coal Utilization Research Association (McKee, J. H., and Adams, A. M., Fuel, 28, 1; 1949) was shown. This employs carbon as fuel and operates at a high temperature, but for various reasons its overall efficiency is low.

\section{United Kingdom Postgraduate Awards}

Published by the Association of Universities of the British Commonwealth, the Universities Yearbook for 1949-50 contained inter alia two useful appendixes; one describing postgraduate awards tenable at universities in the United Kingdom, and the second containing a short list of some of the more important awards tenable by British graduates overseas. In accordance with a resolution at the Congress of Universities of the Commonwealth in July 1948 that each country in the Commonwealth should prepare a list of postgraduate and research awards tenable at its universities by students, the Association of Universities of the British Commonwealth has reprinted these appendixes as a separate booklet. In the first Appendix the awards are set out clearly under different subject headings to indicate those which are open to graduates of United Kingdom universities, those which are open to graduates of British universities overseas, as well as awards which 